\title{
A história das ciências e os saberes tradicionais
}

\section{The history of the sciences and traditional knowledge}

\author{
Francismary Alves da Silva \\ Universidade Federal do Sul da Bahia. \\ fran.ufsb@gmail.com
}

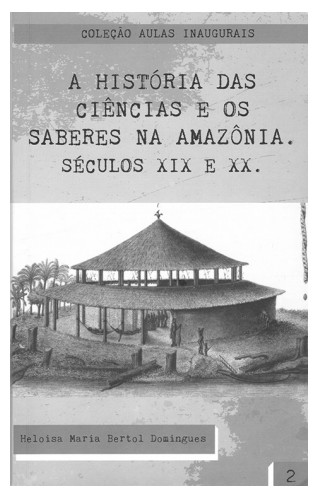

DOMINGUES, Heloisa Maria Bertol. A história das ciências e os saberes na Amazônia: séculos XIX e XX. Rio de Janeiro; São Luís: Casa 8. 2016. 96p.
$\mathrm{O}$ livro A história das ciências e os saberes da Amazônia: séculos XIX e $X X$, da historiadora brasileira Heloisa Maria Bertol Domingues, faz parte da "Coleção Aulas Inaugurais" do Programa de Pós-graduação em Cartografia Social e Política da Amazônia, da Universidade Estadual do Maranhão, coleção que conta com outros dois volumes já publicados. ${ }^{1}$ Com o objeto em mãos, o leitor verá que o livro se divide em duas partes: a aula inaugural em si e uma espécie de memorial da autora-palestrante. No início da aula inaugural, encontramos as falas de duas quebradeiras de coco-babaçu do Maranhão: Maria Nice Machado Aires e Querubina Silva Neta. A presença das falas das duas anfitriãs possivelmente causa estranheza ao leitor acadêmico acostumado com estrutura científico-universitária típica. O lugar de recepção da convidada foi ocupado por representantes de um saber tradicional que em muitos aspectos é silenciado pelo chamado "conhecimento ocidental". É necessário destacar que a transcrição das falas, apesar de aplicar a norma culta da língua portuguesa, conservou traços de oralidades tão ricos e característicos, para não dizer essenciais, dos povos tradicionais. Povos que utilizam a oralidade não apenas como meio de transmissão de seus conhecimentos, mas como lugar de produção dos mesmos. Assim, as falas das quebradeiras de coco ressaltam, de partida, a importância do lugar dos saberes tradicionais em contraste com o conhecimento científico-acadêmico.

Na sequência, Heloisa Domingues inicia sua aula inaugural que leva o nome do livro. Como historiadora do conhecimento dito ocidental, a palestrante inicia sua fala se questionando "o que apresentar na aula inaugural de um mestrado em Cartografia Social e Política da Amazônia"? Apesar de seus trabalhos sobre ciências naturais e a sociedade desenvolvidos desde o mestrado (discurso sobre o índio na Revista IHGB) e o doutorado (sobre agricultura no Brasil Império), apesar de seus trabalhos sobre os saberes tradicionais no Museu de Astronomia e Ciências Afins, a historiadora não apenas entendeu a responsabilidade do convite para proferir a aula inaugural, como viu aí um verdadeiro desafio. O desafio de 
falar de um tema que está na ordem do dia, mas cuja bibliografia disponível ainda é muito restrita, sobretudo na história da ciência. A autora explica que a temática "ciência e saberes tradicionais" só ganhou destaque na historiografia a partir da década de 1990, quando os historiadores perceberam que o enfoque dado à ciência, além de elitista, desconsiderava fatores socioculturais e cotidianos das pesquisas científicas. Heloisa Domingues faz, então, uma revisão historiográfica de trabalhos inaugurais sobre a relação "ciência e saberes tradicionais". Cita o de Henrika Kuklick e Robert Kohler intitulado Science in the field (de 1996); o de Neil Safier intitulado "Global knowledge on the move: itineraries, Amerindian narratives, and deep histories of science" (de 2010); além de trabalhos brasileiros, como os de Alfredo Wagner e de Manuela Carneiro da Cunha, por exemplo. A palestrante também explica que os estudos da área da antropologia e das ciências sociais têm tido, em alguma medida, mais destaque que os de cunho histórico. Isso se dá porque tanto a antropologia quanto as ciências sociais entendem, essencialmente, as relações de "colonização de saberes". São trabalhos que passam a entender, com Antônio Gramsci, as organizações sociais dos saberes; ou, com Pierre Bourdieu, os princípios do "pensamento selvagem" ou "pré-lógico" no seio do pensamento científico ocidental, mais do que na dita excentricidade do próprio saber tradicional. Assim, conforme explica a autora, o pensamento tradicional pode ser reconhecido como base para o pensamento ocidental.

Outro ponto importante é reconhecer que ambas as formas de conhecimento (tradicional ou científico) exercem, em graus diferentes, influência na definição de políticas de desenvolvimento econômico ou social. O conhecimento científico, contudo, tal como as ciências naturais, exemplo explorado pela autora, opera um corte epistemológico entre sujeito e objeto ou, no limite, entre sociedade e ciência. As ciências retiram seu objeto do "ambiente cultural" e o levam ao laboratório, uma verdadeira metáfora para o corte sujeito-objeto. Sabemos que tal corte, tal delimitação sujeito-objeto está na base da separação ciência/não ciência, algo que não ocorre nos saberes dos povos tradicionais. Essa distinção tem consequências nas respectivas narrativas históricas. Assim, muito embora os povos tradicionais já conhecessem várias práticas, técnicas e saberes posteriormente controlados pelas ciências, com o corte sujeito-objeto, a ciência figurará como produtora e detentora dos referidos processos. Conhecemos bem o período histórico em que a ciência domina a produção de borracha extraída das seringueiras da Amazônia, período em que a ciência favorece uma política econômica de exportação do látex. Enquanto isso, a produção de borracha pelos indígenas amazônicos descrita por viajantes do século XVIII foi desconsiderada pela historiografia. Saberes da oralidade, especificidades culturais, ritualísticas ou técnicas artísticas, certamente romperiam a barreira do corte epistemológico da ciência e, portanto, foram esquecidos pela história. Esse é justamente o resgate que a história das ciências pós-1990 realiza. É, também, o resgate histórico que a autora busca estabelecer mediante os saberes tradicionais amazônicos.

A segunda parte do livro traz um memorial intitulado "de como cheguei à história das ciências do Brasil", em que o leitor encontrará uma verdadeira cartografia da formação do historiador das ciências. Apesar de ser historiadora de formação, a autora informa que a maioria dos historiadores das ciências eram (e ainda são) cientistas: físicos, químicos, médicos. Esse cenário, explica, começa a mudar justamente na década de 1990, momento em que os saberes dos povos tradicionais ganham destaque. No mesmo contexto, surgiram críticas à 
célebre tese de Fernando Azevedo e surgiram, também, novos trabalhos de história das ciências, trabalhos diferentes do "velho modelo internalista". Uma história social das ciências, uma história das ciências mais externalista, explica a autora. Visão que aproximaria a história das ciências da história tout court e que iniciaria um processo de reconhecimento de outras formas de conhecimento, como os saberes dos povos tradicionais do Brasil. É justamente nesse contexto historiográfico que se insere a obra de Heloisa Maria Bertol Domingues, momento em que a história das ciências ganha novos objetos, novos atores, novas fontes além dos dados relacionados estritamente aos fatores naturais, científicos e/ou "ocidentais".

Ao final do livro temos a impressão de que, pelas especificidades da história das ciências (cujo objeto é o conhecimento ocidental) ou pela própria identidade bastante característica do historiador das ciências (majoritariamente cientistas), essa área do conhecimento histórico esteve, e em alguma medida continua, afastada dos saberes tradicionais. Talvez, ao se transformar numa história social das ciências (mais "externalista"), a possibilidade de melhor entender o próprio corte epistemológico sujeito-objeto que está na base do problema elencado por Heloisa Domingues (portanto um objeto mais "internalista") também tenha sido abandonado pela história das ciências. Em outras palavras, apesar das iniciativas da história das ciências frente aos conhecimentos tradicionais, a simples adoção de uma história social das ciências (externalista) talvez não tenha aberto plenamente o campo histórico aos saberes tradicionais. Parece que o grande desafio posto à história das ciências é uma compreensão epistemológica, quiçá mais internalista, de si: tanto do conhecimento histórico quanto da própria ciência/conhecimento/saber. A pergunta que persiste reside na estrutura do problema elencado por Heloisa Domingues ao descrever a ascensão do conhecimento científico e também de seus relatos históricos: como entender o conhecimento (científico ou tradicional) sem operar o corte epistemológico e demarcador entre sujeito/objeto, entre ciência/não ciência, entre científico/tradicional, e entre o internalismo/externalismo? O trabalho que Heloisa Maria Bertol Domingues apresenta, além de levantar questionamentos importantes para os historiadores das ciências, oferece indícios do longo caminho a ser trilhado para que a história das ciências estabeleça, de fato, relações não colonizadoras com os saberes tradicionais a partir da reflexão do próprio campo do conhecimento histórico.

\section{NOTA}

${ }^{1}$ Os livros mencionados, bem como várias outras importantes publicações do projeto Nova Cartografia Social da Amazônia, podem ser encontrados em: http://novacartografiasocial.com. Acesso em: 16 set. 2016. 